\title{
Social-Communicative Innovations in Anti-Corruption Activities (Regional Aspect)
}

\author{
Ludmila Stanislavovna Leontieva ${ }^{1}$, Tatiana Viktorovna Khalilova ${ }^{1}$, Liliana Faybergovna Gaynullina ${ }^{2}$ \& \\ Alexander Igorevich Khalilov ${ }^{3}$ \\ ${ }^{1}$ Kazan (Volga region) Federal University, Kazan, Russia \\ ${ }^{2}$ Kazan State University of Architecture and Engineering, Kazan, Russia \\ ${ }^{3}$ Kazan National Research Technological University, Kazan, Russia \\ Correspondence: Ludmila Stanislavovna Leontieva, Kazan (Volga region) Federal University, Kremlevskaya \\ Street, 18, 420800, Kazan, Russia. E-mail: 1s13@ya.ru
}

Received: October 11, 2014

Accepted: October 20, 2014 Online Published: March 27, 2015

doi:10.5539/ass.v11n7p387

URL: http://dx.doi.org/10.5539/ass.v11n7p387

\begin{abstract}
The essence and character of implementation of social communications technologies in the process of anti-corruption activities of organs of power and civil society have been analyzed. The authors based their research on the social communications approach and the "Corruption formula" determined by R.Klitgaard. Based on the analysis of the results opinion surveys, dissatisfaction of the population with the outcomes of anti-corruption policy carried out by the government, demand for transition from declarativity of the principle of transparency of the government to open data, to expansion of anti-corruption enforcement initiated by citizens have been acknowledged. To solve the problems detected integrative communication technologies have been suggested.
\end{abstract}

Keywords: communication, innovation, social technology, corruption, anti-corruption policy, mass media, openness of the government, public and civil communication

\section{Introduction}

Corruption, permeating all areas of life of Russian society, is recognized both by the government and by citizens as a topical social problem demanding complex, systematic countermeasures initiated both by the government and by civil society. Traditional methods of resistance are complemented by innovative social management technologies. Both traditional measures whose effectiveness has been proved and up-to-date, demanded by the time technologies comprise the following components: regulatory, organizational and management, and information communication. As the "social state" declared in the Constitution of the Russian

Federation is based on law, regulatory measures might be classified as solely traditional ones. Yet, the paradox is that the state permeated by corruptive deals had no legislatively defined notion of corruption until the end of the first decade of the current century. Penalty for this deviancy was confined to a few articles of the Criminal Code of the Russian Federation: bribe-taking and bribe-giving (article 290-291); bribery in a profit-making organization (article 204); abuse of official powers (article 285); exceeding official powers (article 286). It was only in 2008 that the National plan on fight against corruption was worked out and Russian Federation Presidential Decree of May 19, 2008 No. 815 "On measures of anti-corruption enforcement" enacted, and on December 25, 2008 the long-awaited Federal Law No. 273-FZ "On anti-corruption enforcement" adopted. In this way, the "age" of full-scale normative legal regulation of fight against corruption in Russia is only 6 years, which is historically insignificant in the framework of the state development. Besides, taking into consideration the social dynamics, the law is continuously being amended, acquiring more up-to-date regulatory prescriptions. Considering that the specific content of any innovation is change, the main function of innovative activity is the function of social change. According to J. Schumpeter, the reasoning behind innovations contains a new moment of dynamicizing economic development (Schumpeter, 1982). There is no doubt that legal regulation of economic relations in the system "administrative elite - business community - citizens", introduction of legal arrangements of lobbyism, legal compliance on the lower level of relationships "government officials - population" might assist reduction of corruption in society, and so "dynamicizing economic development". Considering all that, the 
political decision to form the regulatory legal environment for "recovery"-improvement of society can be ranked among innovative methods of anti-corruption enforcement. According to regulatory prescriptions, administrative management aspect of federal and regional anti-corruption events also undergoes changes. Since diffusion and distribution of organizational and legal innovations is realized in the framework of informational process through acquisition-understanding- distribution, it is information communication component of organizational innovations that is the essence of innovativeness of modern anti-corruption policy.

Information communication technologies include both worldview and technological components, which are closely interdependent. It is a question of using the updating information technological resources of society for mass adoption and rooting of anti-corruption ideas. The subject managing anti-corruption actions must carry out factorial analysis of corruptogenicity of legal norms, social relations and actions, creating an adequate information background. To achieve this goal, legal and organizational methods of counteraction must be complemented and accompanied by anti-corruption social communications. That is why the present article represents the research of the scale, segmental orientation, genre and technical variety of the demanded informational media, social communications technologies in the process of implementation of anti-corruption policy.

\section{Bibliography Review and Hypotheses}

\subsection{Corruption}

The notion of corruption, as of any complicated social phenomenon, is multifaceted. There are various approaches to its definition described. While from the point of neo-liberal approach, corruption is not estimated morally but is understood as optimization with limited resources (Klitgaard R., Rose-Ackerman S.) neo-classical approach emphasizes immorality of this deviancy defining it as abuse. President of the "Indem" Fund and Public Union "Anti-corruption" G. A. Satarov (Satarov, 2004) views corruption as a long since existing phenomenon, comparing it to the notion of social order, while within the framework of institutionalism, corruption of social relations is linked with social earthquakes. In the context of our work, the definition by the Harvard professor Carl Joachim Friedrich is of interest. In the book "Corruption Concepts in Historical Perspective", he maintains a "conventional" approach where corruption is "political pathology", a negative phenomenon affecting both government officials and power institutions (Friedrich, 1989).

\subsection{Corruption and Power}

Based on legislative regulations, the authors resorted to the "Corruption formula" determined by the American scholar R. Klitgaard: "Corruption = Monopoly + Discretion — Accountability" (Klitgaard, 1988) as the theoretical foundation for direction of influence of communication technologies in forming anti-corruption worldview and conduct. Taking into account that, in disregard for the constitutional provisions regarding division of powers, the state in Russia privatized by officials, the main high-status player in the field of corruptive delinquencies are the state organs of executive power, the administrative and political elite. In keeping with the R. Klitgaard formula, "Monopoly" of power, of information plus "Freedom of action" "at discretion" not limited by judicial or legislative power minus "Accountability" implying openness of the government, public control, independent media. The result of the arithmetics in the conditional equation is "ESGO", i.e. executive state government organs, Russian commanding elite.

\subsection{Social Communications Technologies of Anti-Corruption Activities}

Resistance to corruptive delinquencies is implemented in the framework of anti-corruption policy. According to G. A. Satarov, "anti-corruption policy is constant implementation of various and consistent measures of the state and society in the framework of foundations of the constitutional system adopted by the state with the aim of elimination (minimization) of causes and conditions bringing about and feeding corruption in different spheres of life" (Satarov, 2004). Such measures and mechanisms of anti-corruption enforcement include social communications technologies defined by the Russian researchers as "purposeful systemically organized activity on managing communication of a social subject, directed at the solution of some socially significant task" (Gavra, 2010). Innovativeness of such technologies is determined by the changes affecting personality and society with their information influence. Successful realization of any political mindset, including anti-corruption one, is largely determined by information media factors. That is why, the communication nature of contemporary life is closely connected with the communicative essence of power. This aspect of the power phenomenon is investigated in the works by N. Luhmann and J. Habermas. While J. Habermas rationalizes communication trying to maintain orientation at the universality of communicative action (Habermas, 1991), N. Luhmann builds the communicative model in the framework of systemic theory of society as a "self-describing" object, i.e. the peculiarity of communication is determined through the condition of the system (Luhmann, 2012). So, the 
communicative function according to J. Habermas is the main function of power, while N. Luhmann defines power itself as a "symbolically generalized medium of communication" (Luhmann, 1982). As a means of communication, the government generalizes conceptual orientations, administers consolidation of the unified meaning among different subjects in different situations in the form of norms-principles, norms-goals, norms-symbols. From the point of communicative approach, power strengthens its influence when citizens get free access to information and opportunity to participate in information exchange. However, the investigation of the Russian researchers (Leontieva et al., 2014) emphasizes that while the problem of access to information is basically solved, the problem of realization of the "right to participation" in Russia still exists, which means that civil anti-corruption activities and civil control remain just a good intention.

\subsection{Developing Hypotheses}

The analysis of research literature and outcomes of opinion surveys allows to state that corruptogenicity of social relations in Russia requires employing media communication technologies implementation of which is hindered by the following factors, highlighted by the authors as hypotheses:

H1: The administrative and political elite is at the same time both the subject and object of anti-corruption activities. Consequently, society shows a demand for political will and informational openness of the subject in power.

H2: Social activity of citizens motivated at anti-corruption activities is not significantly represented in the information environment, or it is engaged by the official media structures.

H3: The effectiveness of anti-corruption media content requires joint efforts of both official media and independent broadsheet publications which provide a communication ground for the realization of public policy.

\section{Methodology}

Using specific social media examples and statistical data, the authors have attempted to trace and analyze the interconnection between effectiveness of realization of anti-corruption policy and employment of social communications technologies, level of civic media engagement and informational openness of the government.

The work has been implemented in the framework of social communications approach employing general scientific methods of analysis and generalization. To confirm the advanced hypotheses, the information environment of the Republic of Tatarstan has been investigated and secondary analysis of the outcomes of opinion surveys on different levels conducted: international (Transparency International), federal (VCIOM, Levada-Center), regional (Anti-corruption monitoring of the government of the Republic of Tatarstan).

\section{Analyses and Results}

The object of communication technologies is consciousness and conduct of man, forming anti-corruption thought-action pattern of citizens on the basis of both traditional information media means, and employing modern IT. Focus on forming in society intolerance to corruptive conduct is transmitted by the federal and regional legislator pointing out specific information communication measures and methods: ensuring independence of the media, publicity and informational openness of organs of state power, access of citizens to information, development of institutions of public control, employing anti-corruption inspection, monitoring, anti-corruption education and advocacy, etc.

\subsection{Power}

Corruption is the consequence of non-restricted, excessive state regulation and insufficient public information. That is why the R. Klitgaard equation is solved by the equality of the corruption phenomenon and the system of executive state government organs (ESGO). Such understanding and applying this formula to Russian reality is confirmed by the outcomes of opinion surveys at different levels:

In the global rating Transparency International-2013 estimating the degree of corruption among government officials and politicians, Russia ranks 127 out of 177 (Corruption Perceptions Index, 2013).

In the opinion of Russians themselves, it is officials (74\%) who comprise utterly corrupted social groups, along with the police (66\%), judicial and parliamentary systems (59\% and 54\%) (Corruption Barometer, 2013).

In the opinion of the Republic of Tatarstan citizens, the main reason of corruption is insufficient strictness of control of the officials activities, their incomes and expenses (43.5\%) and the possibility of taking decisions at the sole discretion by the officials (31.1\%) (Summary Report, 2014, p. 113).

Thus, the administrative and political elite represents the main object to aim modern anti-corruption social technologies at. At the same time, this actor is the main high-status subject of forming and realization of 
anti-corruption policy, which means selection of information from the point of view of both content and technologies used. The reason behind such pathology of the system allowing the deviant behavior of "political servants", according to R. Klitgaard is monopoly and permissiveness with public control absent.

\subsection{Public Involvement}

To achieve the social optimum, the demand is not only for the political will of the subject at power, his openness, but also for motivated social activity of citizens. Control and accountability of the subject at power imply advanced public and civil communication, engagement of citizens in in politics and taking state decisions. Yet, it is underdevelopment of civil society and absence of public control that act as reasons of corruption in the opinion of 31\% of respondents of the Republic of Tatarstan (Summary Report, 2014, p. 113). The current situation stipulated the beginning of the work of the governmental commission over the Concept of improvement of forms and methods of public control in the Russian Federation and perception of necessity of adopting a structural law "On the foundations of public control in RF". The Draft of the Concept emphasizes that the analysis is of the existing practices testifies to the absence of the whole system of public control in the country, and effectiveness of the measures taken does not improve the quality of the state and municipal government, which leads to soaring corruption and dissatisfaction of citizens (Concept, 2013, p. 2).

Social communications efforts of citizens are manifest both vertically - as participation of civil society structures in preparation, adoption, and control over execution of governmental decisions; and horizontally - as creating (collection, analysis) and distribution of socially significant anti-corruption information.

Based on that, the most innovative information communication method of providing government transparency and creating a reliable population "feedback" mechanism is the Open Government.

\subsection{Anti-Corruption Online Activism of the Power}

Openness of the government is the work of the current government in the mode of "open data" with accessibility of communication channels for the population. In the framework of this statement, by the decree of the government of the Russian Federation of January 30, 2014 N 93-r "The Concept of Openness of Federal Organs of Executive Power" was adopted. Similar programs are implemented in the subjects of the Federation.

For example, in the framework of the Open Government of the Russian Federation, the system "Open Tatarstan" is being formed, which is to comprise 4 blocks: "Electronic services" (138 state services), "People's control" (functioning since 2012), "Online petitions", and "Agencies accountability". It is expected that the new regional portal will provide the population with open information in 24 branches, 26 ministries and agencies. With the aim of reducing corruptogenic pathologies, the following criteria of openness of the Russian power are to be considered: accessibility of socially significant services, visibility of the necessary information, and involvement in governing the region, i.e. public procurement inspection, working out legislative drafts, evaluating effectiveness of the officials' work. Researchers are distinguish two forms of anti-corruption information: "(a) informing the general public on measures for combating corruption in public authorities; b) informing the general public how to protect their rights and legitimate interests of corrupt officials in law enforcement and judicial bodies" (Kabanov, 2013, p. 41).

Electronic communication environment in its current shape offers official websites of organs of power to citizens. Openness of different categories of information is rather non-homogeneous and is varied from region to region. The monitoring of official websites of higher executive state government organs of RF subjects conducted by the Freedom of Information Fund in 2013 showed that the Plan-Program of measures on anti-corruption enforcement in free access is available only to $49,4 \%$ of the federation subjects, including the website of the Republic of Tatarstan government (Results, 2013). It should be pointed out that information representation of Tatarstan official websites is implemented not arbitrarily, but in compliance with the "Unified requirements" of allocation of information on anti-corruption enforcement (Resolution of the Cabinet of Ministers of the Republic of Tatarstan, 2013).

\subsection{Anti-Corruption Online Activism of Citizens}

Actions of the government in the cyberspace are complemented by the mobilizing online activism of citizens: $81 \%$ of the surveyed, according to the Transparency International data, are ready to distribute information about corruption via social networks (Corruption Barometer-2013). Sensible use of the open sources of information (public procurement website, Russian State Register data, officials' incomes and expenses declarations) allowed civic activists to initiate a number of online anti-corruption projects.

Supported by the "Committee of the civic initiatives", the Center of anti-corruption research "Transparency International - Russia" has created the largest updated database of incomes of deputies, officials, and 
representatives of regional authorities and other state organs - http://declarator.org/. The "Declarator" collects data and makes them accessible.

An even more large-scale of implementing public control is linked with the anti-corruption activities of the non-profit Fight against Corruption Fund. Investigations of the Fund founded by A. Navalniy are of various nature. Constraint of corruption in public procurement is implemented in the framework of the RosPil project: for 2011-2013 417 complaints sent and 285 justified, 40 tenders canceled totaling $9.32 \mathrm{bln}$. rub. (Report, 2013). Thus, the civic virtual initiative is of rather significant help for the state budget. A similar project started in Tatarstan: the inter-regional public organization "Anti-corruption" has been functioning since 2013, the Anti-corruption independent newspaper of the Republic of Tatarstan "No Problem", Chistopol (http://gazetabezproblem.ru/) has been published for several years. With limited circulation (3000 copies) and local distribution, the newspaper represents an attempt at realization of independent public information policy on anti-corruption problems. A similar policy is realized by the specialized online publication "First Anti-corruption Media" (http://pasmi.ru). The goal stated by the founder (Inter-regional public interest organization of promoting improvement of state government and anti-corruption policy "Sodeistviye") is the professional information support of anti-corruption policy. The editorial team conducts journalistic investigations, provides information support to entrepreneurs, law-enforcement agencies, discloses facts and corrupt practices. Open information is not only the preventive anti-corruption measure, but it also provides conditions allowing to detect existing facts of illegal activities. Building successful public and civil communication, such publications represent an expert media ground on the problems of fight against corruption.

\subsection{Anti-Corruption Content in the Media}

Evaluation of the population. Network projects being promising, it must be remembered that $32 \%$ of Russians, according to the Levada-Center data, never go online (Volkov \& Goncharov, 2014). That is why it is rather reasonable that the priority source of information concerning the activities of the government for the population of the Republic of Tatarstan are the media: newspapers, TV, radio (77-78\%) (Summary Report, 2014, p. 118).

In compliance with article 12 of the law "On Combating Corruption in the Republic of Tatarstan", the system of state orders and grants stimulates anti-corruption advocacy in electronic and printed media of the republic (Law of the Republic of Tatarstan, 2006). Mass media must conduct "awareness building in society on fighting corruption in any form, breeding the sense of civic responsibility for outcomes of the realized anti-corruption programs, confidence-building between population and the power". Anticorruption information should become a genuine instrument of socialization. Hence it is important to "study the social values (meanings) that exist, living in the world of pragmatics, namely in the field of communication" (Taysina, 2014, p. 199). Anti-corruption advocacy in the media is known to more than half of Tatarstan respondents - 57\% (Summary Report, 2014, p. 114). By the initiative or with the participation of heads of organs of power, the media of the republic have issued 1358 materials concerning corruption. Of them: 163 TV spots, 185 printed materials, 269 at the websites of electronic newspapers and Internet portals, 741 in the district media (Summary Report, 2014, p. 88), i.e. anti-corruption information events employ all the technologically feasible range of modern communication media.

Traditional methods of state anti-corruption advocacy comprise public events and competition known from the Soviet time, including those for the media. In Tatarstan, these are the annual republican competition "Corruption: journalist's view", the annual Anti-corruption marathon representing an array of promo and advocacy events dedicated to the international Day of fight against corruption.

Quality and quantity of information about anti-corruption events in the local media for 2013 is evaluated by the population as follows: $39.6 \%$ of respondents consider that information is provided to the extent required, $35.1 \%$ think that information is sufficient, but it does not cover all aspects of the problem (Summary Report, 2014, p. 117). Altogether, $74.7 \%$ of respondents estimate anti-corruption information presented by the local media as sufficient. Federal and republican newspapers included, as the volume and quality of information in them are estimated even higher $(85.6 \%$ and $85 \%$ correspondingly), we can draw a conclusion about information richness in the region on this issue.

Despite the information richness, $12 \%$ to $23 \%$ of respondents are dissatisfied with the media coverage of anti-corruption activities (Summary Report, 2014, p. 117), which testifies to the necessity of enhancing alternative forms of social communication in this problem.

The examined examples testify to growing attention of the government and civil society to the anti-corruption problem. However, international, Russian, and republican opinion surveys demonstrate dissatisfaction of the population with the results of the conducted anti-corruption policy: 
According to the Transparency International data, only 5\% of the surveyed Russians consider the anti-corruption efforts of the government effective, no one called the conducted policy "very effective" (Corruption Barometer-2013). It should be pointed out that such low evaluation was given in 2012- 2013 when the media were full of headline-making investigations, which nevertheless had no influence on the level of legitimization of the power actions.

According to the VCIOM investigation (VCIOM, 2013), the percentage of Russians considering that the anti-corruption policy of the government is not effective is higher than those who point out positive trends (52\% and $45 \%$ correspondingly).

According to the anti-corruption monitoring of the Republic of Tatarstan for 2013 (Summary Report, 2014, p. 113), most respondents $(52.7 \%)$ consider that the measures taken by the government can only in part reduce corruptive delinquencies.

\section{Conclusions}

The conducted analysis of the information environment allows to state that fight against corruption is waged both in real world and in virtual space employing both traditional and innovative communication technologies. However, the estimation of effectiveness of the state anti-corruption policy by the population is low. This testifies to the fact that the society requires transition:

- From declarativity of the government transparency principle to open data;

- From the state of lethargy in the field of public politics to initiated by citizens public involvement and horizontal communication;

- From politically engaged media to independent discourse actualizing pluralism of communication technologies of anti-corruption enforcement.

These conclusions correspond to our hypotheses confirmed by sociological data and practical examples of the media. Based on social communications situation in Russia, we consider that the main trends of information support of anti-corruption policy must be focused on intensive development of the following social communications technologies:

- Open government services;

- Independent anti-corruption media;

- Anti-corruption communities of civic activists in social networks;

- Motivation of the journalistic community through the system of competitions and grants provided by state institutions, NGOs, and funds;

- Social anti-corruption advertising.

Thus, optimization of the anti-corruption system of public communication requires developing complex social innovation technologies integrating information communication, media, advertising, reflexive motivational, and PR approaches.

\section{References}

Concept of improvement of forms and methods of public control in the Russian Federation. (2013). Retrieved from http://www.opso66.ru/upload_files/3kontseptsiya-sovershenstvovaniya-form-i-metodov-obshchestven nogo-kontrolya-v-rf.pdf

Corruption Perceptions Index 2013: Transparency International. Retrieved from http://www.transparency.org/ cpi2013/in_detail

Corruption will be overcome not by the government, but by citizens. Global Corruption Barometer-2013/ Transparency International. Retrieved from http://www.transparency.org.ru/barometr-mirovoi-korruptcii/ korruptciiu-pobedit-ne-pravitelstvo-a-grazhdane

Fight Against Corruption: Step By Step To the Goal? (2013). VCIOM, (press issue), 2278. Retrieved from http://www.wciom.ru/index.php?id=459\&uid $=113912$

Friedrich, C. J. (1989). Corruption Concepts in Historical Perspective. In A. J. Heidenmeier, M. Johnston, \& V. T. Levine (Eds.), Political corruption. A handbook (pp. 15-24). New Brunswick (etc.): Transaction Publishers.

Gavra D. P. (2010). Social Communications Technologies: Essence, Structure, Functions. Retrieved from http://www.jarki.ru/wpress/2010/02/28/937/ 
Habermas, J. (1981). Theorie des kommunikativen Handelns. Bd. 1. Frankfurt: Suhrkamp.

Kabanov, P. A. (2013). Anticorruption advertasing in Republic of Tatarstan as an informational meansl of corruption counteraction: issues and perspectives. Aktual'niye problemy ekonomiki i prava, 4, 38-45.

Klitgaard, R. (1988). Controlling Corruption. University of California Press, Berkeley and Los Angeles.

Law of the Republic of Tatarstan dated 4.05.2006 \#34. On Combating Corruption in the Republic of Tatarstan. Retrieved from http://minjust.tatarstan.ru/rus/info.php?id=103347

Leontieva, L., Gaynullina, L., \& Cherepanova, E. (2014). Legal Boundaries of Communication in Russia: Current Approaches to Research. World Applied Sciences Journal, 30(2), 147-151. Retrieved from http://www.idosi.org/wasj/wasj30(2)14/4.pdf

Luhmann, N. (1982). Trust and Power. New York: John Wiley \& Sons Inc.

Luhmann, N. (2012). Theory of Society. Stanford: Stanford University Press.

Report on proceedings for 2011-2012: RosPil. Retrieved from http://www.rospil.info/

Report on the Fund proceedings for 2013. Retrieved from http:// www.report.fbk.info/

Resolution of the Cabinet of Ministers of the Republic of Tatarstan on April 4, 2013 \# 225. On approval of the Uniform Requirements for placement and filling sections of the official websites of the executive authorities of the Republic of Tatarstan in the information and telecommunications network Internet on combating corruption. Retrieved from http://minjust.tatarstan.ru/rus/info.php?id=103347

Results of Monitoring the Official Websites of the Federal Executive Bodies, 2013: Open Knowledge Foundation. Retrieved from http://www.svobodainfo.org/ru/node/2727

Satarov, G. A. (2004). Anti-corruption policy. Moscow: INDEM Fund, AA SPAS. Retrieved from http://www.indem.ru/corrupt/Uc2004/UcAKP2004.htm

Schumpeter, J. (1982). The Theory of Economic Development: An inquiry into profits, capital, credit, interest and the business cycle. Piscataway, NJ: Transaction Publishers.

Summary Report on Corruption and Measures of Anti-corruption Policy in the Republic of Tatarstan in 2013. Kazan, 2014. Retrieved from http://ftp.prav.tatar.ru/anticor/otchet_2013.pdf

Taysina, E. A. (2014). Philosophical questions of semiotics. St.Petersburg: Aletheia.

Volkov, D., \& Goncharov, S. (2014). Russian Media Landscape: TV, press, Internet. Levada-Center. Retrieved from http://www.levada.ru/17-06-2014/rossiiskii-media-landshaft-televidenie-pressa-internet

\section{Copyrights}

Copyright for this article is retained by the author(s), with first publication rights granted to the journal.

This is an open-access article distributed under the terms and conditions of the Creative Commons Attribution license (http://creativecommons.org/licenses/by/3.0/). 